\title{
NTP2 IPS \\ MITIGASI BENCANA GEMPA BUMI BERBASIS KEARIFAN LOKAL MASYARAKAT ROTE KABUPATEN ROTE NDAO PROVINSI NUSA TENGGARA TIMUR
}

\author{
Jonas Thene ${ }^{1}$
}

\begin{abstract}
Abstrak
Penelitian ini bertujuan untuk menemukan pengetahuan lokal masyarakat Rote Ndao menghadapi gempabumi. Metode penelitian yang digunakan adalah metode kualitatif yang difokuskan pada penggalian informasi tentang pengetahuan dan pengalaman masyarakat Rote Ndao di Kabupaten Rote Ndao dalam menghadapi bencana gempabumi. Penelitian ini dilakukan di dua tempat, yaitu di Desa Mukebuku dan Desa Lakamola Kecamatan Rote Timur Kabupaten Rote Ndao. Dalam penelitian ini dilibatkan 20 orang sebagai informan; yang ditentukan dengan cara bola salju dan disertai dengan kesediaan mereka terlibat dalam penelitian ini. Hasil penelitian sebagai berikut. Pertama, masyarakat Rote Ndao tidak memiliki pengetahuan tentang gempabumi, mereka hanya memiliki mitos tentang gempabumi. Mitos bagi mereka adalah untuk mendekatkan warga masyarakat pada inti kehidupannya atau pada jatidirinya yang sejati; berkat mitos, setiap warga akan dapat bertemu, dengan dirinya sendiri yang khas, sekaligus pada saat yang sama pula mereka akan berjumpa dengan manusia sesama juga alam semesta, dan Yang Ilahi. Mitos memberi inspirasi kepada manusia untuk memelihara serta mengembangkan sebuah keserasian hidup bersama dalam tatanan masyarakat: antara makro-kosmos, mikro-kosmos dan Yang Tak Kelihatan. Kedua, pengalaman masyarakat Rote Ndao dalam menghadapi bencana gempabumi, mereka menggunakan kearifan lokal, berteriak ketika berlangsung gempa ami nai ia o... Mereka gembira karena adanya keyakinan bahwa tahun yang sedang berjalan akan mendatangkan kesuburan tanah dan panen pertanian akan melimpah. Perasaan senasiblah yang menggerakkan manusia untuk sadar akan makna kolektivitasnya sebagai makluk sosial. Dalam hal ini, gempa yang meluluhlantakan kehidupan masyarakat silam telah menyemaikan benih solidaritas dan kesetiakawanan. Ketiga, masyarakat Rote Ndao tidak memiliki pengetahuan tentang mitigasi bencana gempabumi, pengalamannya adalah dengan menggunakan kearifan lokal.
\end{abstract}

Katakunci: gempa bumi, mitigasi, kearifan lokal, masyarakat Rote Ndao.

\begin{abstract}
This study aims to find local knowledge society Rote Ndao face earthquakes. The method used is a qualitative method that is focused on extracting information about the knowledge and experience of communities in Rote Ndao Rote Ndao in the face of the earthquake disaster. This research was conducted in two places, namely in the Village Lakamola and Village Mukebuku Eastern District of Rote Rote Ndao. In this study involved 20 people as informers; which is determined by a snowball and accompanied by their willingness to be involved in this research. The following results. First, Rote Ndao people have no knowledge of earthquakes, they just have myths about earthquakes. Myth for them is to bring citizens at the core of its life or the true identity; thanks to the myth, every citizen will be able to meet with his own distinctive, while at the same time they will also meet with fellow humans are also the universe, and the Divine. Myth inspire people to maintain and develop a harmonious living together in a community setting: between macro-cosmos, micro-cosmos and Invisible Invisible. Secondly, experience Rote Ndao society in the face of the earthquake disaster, they use local wisdom, screaming when the quake lasted ami nai ai $o$... They were happy because of their belief that the current year will bring soil fertility and agricultural crops will be abundant. Senasiblah feeling that drives people to be aware of the meaning of the collectivity as social beings. In this case, the earthquake that devastated people's lives ago has sowed seeds of solidarity, and solidarity. Third, Rote Ndao people have no knowledge of earthquake disaster mitigation, his experience is to use local wisdom.
\end{abstract}

Keywords: earthquake, mitigation, local knowledge, community Rote Ndao.

\footnotetext{
${ }^{1}$ Jurusan Pendidikan Sejarah FKIP Universitas Nusa Cendana Kupang_jonas_thene@yahoo.com
} 


\section{PENDAHULUAN}

Gempabumi tektonik adalah gerakan atau hentakan bumi secara tiba-tiba akibat pelepasan energi yang terakumulasi disebabkan oleh tumbukan lempeng litosfer, pergeseran sesar dari lepasan akumulasi energi di dalam bumi yang sifatnya sangat merusak, untuk suatu jangka waktu tertentu yang berasal dari suatu wilayah yang terbatas dan menyebarkan dari satu titik ke segala arah dengan peringatan dini yang sangat kecil. Menurut Boen (2000) salah satu teori yang digunakan untuk menjelaskan bagaimana terjadinya gempabumi tektonik adalah Elastic Rebound Theory, yang ditampilkan Reid. Teori ini diformulasikan sebagai berikut. Dalam kulit bumi ada aktivitas geologis yang mengakibatkan pergerakan relatif suatu massa batuan di dalam kulit bumi terhadap yang lain. Gaya-gaya yang menimbulkan pergerakan batuan-batuan ini dinamakan gayagaya tektonik. Batu-batuan bersifat elastik dan dapat menimbulkan pergerakan regangan bilamana ditekan atau ditarik melampaui kekuatannya, batuan tersebut akan hancur ke arah terlemah yang disebut sesar (fault). Batuan yang hancur tersebut akan melepaskan sebagian atau seluruh tegangan untuk kembali ke dalam keadaan yang semula yang bebas tegangan. Hancurnya batuan di dalam kulit bumi tersebut akan disertai dengnpemancaran gelombanggelombang gempa ke segala arah, bahkan sampai jauh sekali tergantung dari banyaknya energi yang dilepaskan. Kulit bumi tidak homogen dan terdiri dari bermacam-macam bahan dan lapisan, gelombang-gelombang tersebut dalam perjalanannya mencapai permukaan bumi, yaitu diredam, dipantulkan, dbiaskan pada batas-batas lempeng litosfer, lapisan-lapisan maupun pada permukaan. Akibatnya, jalannya gelombang-gelombang dengan cepat menjadi tidak beraturan, rumit, dan sulit untuk diprediksi. Hal ini tergantung dari arah terjadinya sesar, apakah itu sesar normal dan sesar naik (dip slip), atau sesar samping ke kanan dan sesar samping ke kiri (srike slip).

Potensi kerugian yang ditimbulkan akibat bencana gempabumi tektonik pada suatu wilayah dan kurun waktu tertentu yang dapat berupa kematian, luka, sakit, jiwa terancam, hilangnya rasa aman, mengungsi, kerusakan atau kehilangan harta, dan gangguan kegiatan masyarakat, dinamakan resiko bencana gempabumi tektonik. Mitigasi bencana gempabumi tektonik adalah serangkaian upaya untuk mengurangi risiko bencana gempabumi tektonik baik melalui pembangunan fisik maupun penyadaran dan peningkatan kemampuan masyarakat menghadapi ancaman bencana gempabumi tektonik. Pemberdayaan masyarakat dalam mitigasi bencana gempabumi dapat dilakukan melalui kearifan lokal masyarakat (Angin, 2015).

Data dan informasi tentang pengetahuan, pengalaman masyarakat tentang gempabumi dan kearifan lokal masyarakat dalam mitigasi bencana gempabumi belum tersedia, padahal data dan informasi sangat diperlukan untuk menyiapkan masyarakat siaga bencana, karena daerah ini rawan terhadap gempabumi tektonik. Masalah ini dirumuskan sebagai berikut: (1) bagaimanakah pengetahuan lokal masyarakat Desa Mukebuku, dan Desa Lakamola di Kecamatan Rote Timur tentang gempabumi tektonik?, (2) bagaimanakah pengalaman masyarakat Desa Mukebuku, dan Desa Lakamola di Kecamatan Rote Timur dalam menghadapi bencana gempabumi tektonik?, (3) bagaimanakah pengetahuan dan pengalaman masyarakat Desa Mukebuku, dan Desa Lakamola di Kecamatan Rote Timur dalam mitigasi bencana gempabumi tektonik?.

Penelitian ini bertujuan untuk mengidentifikasi dan merumuskan: (1) pengetahuan masyarakat Desa Mukebuku, dan Desa Lakamola di Kecamatan Rote Timur Kabupaten Rote Ndao tentang bencana gempabumi tektonik, (2) pengalaman masyarakat Desa Mukebuku, dan Desa Lakamola di Kecamatan Rote Timur Kabupaten Rote Ndao dalam menghadapi bencana gempabumi tektonik, dan (3) pengetahuan dan pengalaman masyarakat Desa Mukebuku, dan Desa Lakamola di Kecamatan Rote Timur Kabupaten Rote Ndao dalam mitigasi bencana gempabumi tektonik. Hasil penelitian ini dapat dijadikan bahan masukan bagi masyarakat dan pemerintah setempat dalam rangka sosialisasi tentang mitigasi bencana gempabumi tektonik.

\section{METODE PENELITIAN}

Jenis penelitian ini deskriptif interpretatif. Penelitian ini dilakukan di Desa Mukebuku, dan Desa Lakamola di Kecamatan Rote Timur Kabupaten Rote Ndao. Dalam penelitian ini dilibatkan 20 orang sebagai informan; yang ditentukan dengan cara bola salju (snow ball) 
dan disertai dengan kesediaan mereka terlibat dalam penelitian. Penentuan informan bola salju ini dimulai dengan menentukan satu atau beberapa orang untuk diwawancarai. Informan tersebut berperan sebagai titik awal pemilihan informan. Informan selanjutnya ditetapkan berdasarkan petunjuk dari informan sebelumnya. Petunjuk tersebut diberikan menyangkut mereka yang dapat memberikan informasi mengenai gempabumi teknik, bencana gempabumi tektonik, kearifan lokal masyarakat dalam mitigasi bencana gempabumi tektonik. Informan ditetapkan 20 orang, terdiri dari 10 informan dari Desa Mukebuku dan 10 informan dari Desa Lakamola Kecataman Rote Timur Kabupaten Rote Ndao. Kedua desa ini dan desa-desa sekitarnya sering mengalami gempabumi tektonik.

Data dan informasi tentang pengetahuan lokal gempabumi, pengalaman menghadapi gempabumi, pengetahuan dan pengalaman mengenai mitigasi bencana gempabumi masyarakat Desa Mukebuku dan Desa Lakamola, dianalisis secara deskriptif interpretatif. Dengan analisis deskriptif interpretatif, dapat ditemukan pengetahun masyarakat tentang gempabumi tektonik, pengalaman menghadapi bencana gempabumi, pengetahuan dan pengalaman masyarakat daerah penelitian dalam mitigasi bencana gempabumi tektonik.

\section{HASIL DAN PEMBAHASAN}

Masyarakat Desa Mukebuku dan Lakamola Kecamatn Rote Timur di Kabupaten Rote Ndao tidak memiliki pengetahuan tentang gempabumi tektonik. Masyarakat hanya memiliki mitos tentang gempabumi tektonik. Masyarakat kedua desa penelitian percaya bila Bumi diseimbangkan oleh hewan ular naga. Gempabumi tektonik akan terjadi apabila ular naga tidak diberi sesaji, sehingga ia berontak karena kemurkaan manusia dan menggetarkan bumi. Mitos memberi inspirasi kepada manusia untuk memelihara serta mengembangkan sebuah keserasian hidup bersama dalam tatanan masyarakat: antara makro-kosmos, mikrokosmos dan Yang Tak Kelihatan (Neonbasu, 1995). Ketika gempabumi tektonik terjadi masyarakat kedua desa berteriak ami nai ia o... (kami ada), karena ular naga tersebut merasa tidak ada manusia lagi dibumi yang memberikan dia "makan". Gempabumi tektonik bagi masyarakat Desa Mukebuku dan Lakamola di
Kecamatan Rote Timur Kabupaten Rote Ndao merupakan simbol kesuburan untuk pertanian. Gempabumi bagi masyarakat kedua desa ini memberikan kesuburan bagi tumbuh kembangnya pohon lontar (Borassus) penopang kehidupan ekonomi masyarakat. Ditilik dari segi sosial, budaya, dan ekonomi masyarakat Rote merupakan satu masyarakat yang tangguh menghadapi tantangan dan pandai bicara (Fox, (1977; 1995). Menurut Gianto (1958) masyarakat Rote merupakan msyarakat yang tangguh dalam ekonomi Borassus.

Pengalaman masyarakat Desa Mukebuku dan Desa Lakamola di Kecamatan Rote Timur dalam menghadapi bencana gempabumi tektonik, mereka menggunakan kearifan lokal, berteriak ketika berlangsung gempabumi tektonik: "ami nai ia o...". Perasaan senasiblah yang menggerakkan manusia untuk sadar akan makna kolektivitasnya sebagai makhluk sosial. Masyarakat Desa Mukebuku dan Desa Lakamola menyadari betul, kerjasama yang baik antara manusia dengan sesamanya sangat dibutuhkan, dalam suka dan duka. Masyarakat Desa Mukebuku dan Lakamola di Kecamatan Rote Timur Kabupaten Rote Ndao memiliki filosofi keharmonisan, harmonis dengan Ilahi, sesama, dan alam.

Masyarakat Desa Mukebuku dan Lakamola di Kecamatan Rote Timur Kabupaten Rote Ndao tidak memiliki pengetahuan mitigasi bencana gempabumi teknonik secara mutakhir. Pengalamannya adalah dengan menggunakan kearifan lokal. Menurut mereka kapan terjadinya gempabumi tektonik terjadi tidak diketahui, modal mereka hanyalah berteriak "ami nai ia o...", sehingga masyarakat berhamburan keluar rumah untuk mencari tempat-tempat aman seperti di lapangan terbuka, dan membangun barak untuk melindungi orangtua dan anak-anak.

Gempabumi tektonik adalah gerakan atau hentakan bumi secara tiba-tiba akibat pelepasan energi yang terakumulasi disebabkan oleh tumbukan lempeng litosfer, pergeseran sesar dari lepasan akumulasi energi di dalam bumi yang sifatnya sangat merusak, untuk suatu jangka waktu tertentu yang berasal dari suatu willayah yang terbatas dan menyebarkan dari satu titik ke segala arah dengan peringatan dini yang sangat kecil. Menurut Boen (2000) salah satu teori yang digunakan untuk menjelaskan bagaimana terjadinya gempabumi tektonik adalah Elastic Rebound Theory, yang ditam- 
pilkan Reid. Teori ini diformulasikan sebagai berikut. Dalam kulit bumi ada aktivitas geologis yang mengakibatkan pergerakan relatif suatu massa batuan di dalam kulit bumi terhadap yang lain. Gaya-gaya yang menimbulkan pergerakan batuan-batuan ini dinamakan gaya-gaya tektonik. Batu-batuan bersifat elastik dan dapat menimbulkan pergerakan regangan bilamana ditekan atau ditarik melampaui kekuatannya, batuan tersebut akan hancur ke arah terlemah yang disebut sesar (fault). Batuan yang hancur tersebut akan melepaskan sebagian atau seluruh tegangan untuk kembali ke dalam keadaan yang semula yang bebas tegangan. Hancurnya batuan di dalam kulit bumi tersebut akan disertai dengan pemancaran gelombang-gelombang gempa ke segala arah, bahkan sampai jauh sekali tergantung dari banyaknya energi yang dilepaskan. Kulit bumi tidak homogen dan terdiri dari bermacam-macam bahan dan lapisan, gelombang-gelombang tersebut dalam perjalanannya mencapai permukaan bumi, yaitu diredam, dipantulkan, dbiaskan pada batas-batas lempeng litosfer, lapisan-lapisan maupun pada permukaan. Akibatnya, jalannya gelombanggelombang dengan cepat menjadi tidak beraturan, rumit, dan sulit untuk diprediksi. Hal ini tergantung dari arah terjadinya sesar, apakah itu sesar normal dan sesar naik (dip slip), atau sesar samping ke kanan dan sesar samping ke kiri (srike slip).

Laut Timor merupakan suatu cekungan daerah busur depan Lempeng Australia, suatu wilayah potensi menjadi pusat gempabumi tektonik. Masyarakat Desa Mukebuku dan Lakamola di Kecamatan Rote Timur Kabupaten Rote Ndao tidak memiliki pengetahuan tentang gempabumi tektonik. Mereka tidak memahami bahwa Laut Timor merupakan suatu cekungan daerah busur depan Lempeng Australia yang bergerak ke utara, suatu wilayah potensi pusat gempabumi tektonik. Pengalaman masyarakat Desa Mukebuku dan Lakamola di Kecamatan Rote Timur Kabupaten Rote Ndao dalam menghadapi bencana gempabumi tektonik, mereka menggunakan kearifan lokal, berteriak ketika berlangsung gempabumi: bumi tektonik ““'ami nai ia o...”. Perasaan senasiblah yang menggerakkan manusia untuk sadar akan makna kolektivitasnya sebagai makhluk sosial. Masyarakat Desa Mukebuku dan Lakamola di Kecamatan Rote Timur Kabupaten Rote Ndao menyadari betul, kerjasama yang baik antara manusia dengan sesamanya sangat dibutuhkan, dalam suka dan duka. Masyarakat Desa Mukebuku dan Lakamola di Kecamatan Rote Timur Kabupaten Rote Ndao memiliki filosofi keharmonisan, harmonis dengan Ilahi, sesama, dan alam.

Mitigasi bencana gempabumi tektonik adalah serangkaian upaya untuk mengurangi risiko bencana gempabumi tektonik, baik melalui pembangunan fisik maupun penyadaran dan peningkatan kemampuan masyarakat menghadapi ancaman bencana gempabumi tektonik. Masyarakat Desa Mukebuku dan Lakamola di Kecamatan Rote Timur Kabupaten Rote Ndao tidak memiliki pengetahuan tentang mitigasi bencana gempabumi. Tektonik. Pengalamannya adalah dengan menggunakan kearifan lokal. Menurut mereka kapan terjadinya gempabumi tertonik terjadi tidak diketahui, modal mereka hanyalah berteriak "ami nai ia o...". ketika terjadi bencana gempabumi tektonik, masyarakat berhamburan keluar rumah untuk mencari tempat-tempat aman seperti di lapangan terbuka, dan membangun barak untuk melindungi orangtua dan anak-anak.

\section{PENUTUP}

Gempabumi tektonik gerakan atau hentakan bumi secara tiba-tiba akibat pelepasan energi yang terakumulasi disebabkan oleh tumbukan lempeng litosfer, pergeseran sesar dari lepasan akumulasi energi di dalam bumi yang sifatnya sangat merusak, untuk suatu jangka waktu tertentu yang berasal dari suatu willayah yang terbatas dan menyebarkan dari satu titik ke segala arah dengan peringatan dini yang sangat kecil. Masyarakat Desa Mukebuku dan Lakamola di Kecamatan Rote Timur Kabupaten Rote Ndao tidak memiliki pengetahuan tentang gempabumi tektonik. Mereka tidak memahami bahwa Laut Timor merupakan suatu cekungan daerah busur depan Lempeng Hindia-Australia, suatu wilayah potensi menjadi pusat gempabumi tektonik. Pengalaman masyarakat Desa Mukebuku dan Lakamola di Kecamatan Rote Timur Kabupaten Rote Ndao dalam menghadapi bencana gempabumi tektonik, mereka menggunakan kearifan lokal, berteriak ketika berlangsung gempabumi: "ami nai ia o...". Perasaan senasiblah yang menggerakkan manusia untuk sadar akan makna kolektivitasnya sebagai makluk sosial. Masyarakat Desa Mukebuku dan Lakamola di Kecamatan Rote 
Timur Kabupaten Rote Ndao menyadari betul, kerjasama yang baik antara manusia dengan sesamanya sangat dibutuhkan, dalam suka dan duka. Masyarakat Desa Mukebuku dan Lakamola di Kecamatan Rote Timur Kabupaten Rote Ndao memiliki filosofi keharmonisan, harmonis dengan Ilahi, sesama, dan alam.

Serangkaian upaya untuk mengurangi risiko bencana gempabumi tektonik, baik melalui pembangunan fisik maupun penyadaran dan peningkatan kemampuan masyarakat menghadapi ancaman bencana gempabumi tektonik, dinamakan mitigaasi bencana gempabumi tektonik. Masyarakat Desa Mukebuku dan Lakamola di Kecamatan Rote Timur Kabupaten Rote Ndao tidak memiliki pengetahuan tentang mitigasi bencana gempabumi. Kearifan lokal (local wisdom) dapat dipahami sebagai sejumlah gagasan, nilai-nilai, pandangan-pandangan setempat yang bersifat bijaksana, penuh kearifan, bernilai baik, yang tertanam dan diikuti oleh anggota masyarakatnya. Pemberdayaan masyarakat berbasis kearifan lokal dapat digunakan untuk mengurangi resiko bencana gempabumi tektonik.

\section{DAFTAR RUJUKAN}

[1] Angin, Ignasius Suban., 2015, Mitigasi Bencana Alam Gempabumi Berbasis Kearifan Lokal Masyarakat Lamaholot Flores Timur, Makalah disajikan dalam Seminar Nasional Kemandirian Daerah Dalam Mitigasi Bencana Menuju Pembangunan Berkelanjutan, Program Studi Magister Pendidikan Kependudukan dan Lingkungan Hidup Universitas Sebelas Maret Bekerjasama Dengan Ikatan Ahli Kebencanaan Indonesia (IABI), Surakarta, 19 September 2015.

[2] Boen, A., 2000, Earthquakes and Geological Discovery, New York: W.H. Freeman.

[3] Fox, J. James., 1977, Bahasa, Sastra dan Sejarah: Kumpulan Karangan Masyarakat Pulau Rote, Jakarta: Sinar Harapan.

[4] Fox, J. James., 1995, Panen Lontar: Perubahan Ekologi dalam Kehidupan Masyarakat Pulau Rote dan Sawu, Jakarta: Sinar Harapan.

[5] Gianto, 1958, Pulau Rote Pagar Selatan Indonesia, Jakarta: Ganaco.

[6] Menteri Energi dan Sumberdaya Mineral RI, 2011, Peraturan Menteri Energi dan Sumberdaya Mineral Nomor: 15 Tahun 2011 Tentang Pedoman Mitigasi Bencana, Jakarta: Menteri Energi dan Sumberdaya Mineral RI.

[7] Neonbasu, Gregor.P., 1995, "Pembangunan NTT dalam Tinjauan Kata dan Analisis: Sebuah Telaahan Filsafat Sosial dan Kultural", dalam Alo Liliweri dan P. Gregor Neonbasu (Peny.) Perspektif Pembangunan: Dinamika dan Tantangan Pembangunan Nusa Tenggara Timur, Kupang: Yayasan Citra Insan Pembaru, 111-139.

[8] Sumarmi dan Ach. Amirudin, 2014, Geografi Lingkungan Dengan Blanded Learning Berbasis Kearifan Lokal, Malang: Adytia Media. 